\title{
1916 YILINDAKİ KIRGIZ MİLLÎ MÜCADELESİ: ÜRKÜN
}

\section{Mayramgül DIYKANBAYEVA*}

\section{Özet}

Kırgızlar Orta Asya'da yaşayan Müslüman Türk boylarından biridir. Kaynaklarda verilen bilgiler, Kırgızların en eski Türk boylarından biri olduğunu göstermektedir. İlk devletlerini M.Ö. III. asırda kurmuş olan Kırgızlar, XVI - XVII. yüzyıllarda Kalmuk ve Moğollara karşı mücadele vermişler. XVIII. yüzyılda Türkistan'da teşekkül eden hanlıklara tabi olan Kırgızlar, 1860 - 1861 yıllarında ise Ruslar tarafından toprakları işgal edilmiştir. 1990 yılında Sovyetler Birliği'nin dağılmasıyla 1991 yılında bağımsızlıklarına kavuşmuşlardır.

Tarihte uzun yollardan geçen Kırgızlar, 19. yüzyılın sonlarına doğru Çarlık rejiminin yönetimi altında yaşamaya başlamıştır. Çarlık Rusya'sı öncelikle Kazak bozkırlarını ele geçirmiş, sonra Tanrı Dağlarına Sibirya tarafindan girerek Türkistan'ı işgal etmiştir. 1867 yılında Çarlık Rusya'sı Türkistan'1 önce bölgelere, sonra da eyaletlere bölmüştür. Bölünmüş olan topraklara Rusları yerleştirmiş ve bu topraklarda yeni Rusya yaratmayı amaç edinmişlerdir.

Bu yazıda Kırgızların 1916 yılındaki ayaklanma ve Çin’e kaçış sebepleri sırasıyla anlatılmış ve edebî eserlerden örnekler verilmiştir.

Anahtar Sözcükler: Orta Asya, Kırgızlar, Çarlık Rusya'sı, Türkistan, Sovyetler Birliği, Çin, Çarlık Rejimi.

\section{KYRGYZ NATIONAL STRUGGLE IN 1916: ÜRKÜN}

\begin{abstract}
Kyrgyz is one of the Muslim Turkish tribes in Central Asia. Information provided from Sources shows that Kyrgyz is one of the oldest Turkish tribes. Kyrgyz who founded the first state in III. century BC, in the XVI - XVII. centuries struggled against the Kalmyks and Mongols and in the XVIII. century have been subject to khanates formed in Turkestan. During 1860 1861 their lands occupied by the Russians, in 1990 after the disintegration of the Soviet Union again gained their independence in 1991.

On the date, Kyrgyz who last long way, towards the end of the 19th century began to live under the rule of the Tsarist regime. In 1867 Tsarist Russia before divided the Turkestan into region, and then states. They placed Russians to the divided land and have set out to create a new Russia at this place.

In this article, the reasons uprising of Kyrgyz in 1916 and escape to China, respectively, have been described and given examples from literary works.
\end{abstract}

Keywords: Central Asia, Kyrgyz, Tsarist Russia, Turkestan, Soviet Union, China, Tsarist Regime.

\footnotetext{
* Yrd. Doç. Dr.; Atatürk Üniversitesi, Edebiyat Fakültesi, Çağdaş Türk Lehçeleri ve Edebiyatları Bölümü, mayramgul@hotmail.com.
} 


\section{Giriș:}

Kırgızlar, hayatlarını Orta Asya'da sürdüren en eski Türk boylarından biridir. Kırgızlara ait ilk bilgiler Çin kaynaklarında geçmektedir. Kaynaklarda bulunan bilgilere göre Kırgızlar, ilk devletlerini M.Ö. III. asırda kurmuşlardır. Yine Çin kaynaklarından aldığımız bilgilere göre, VI - IX. yüzyıllar arasında ilk devletlerini kuran Kırgızlar, fiziksel olarak kızıl yüzlü, sarı saçlı, mavi gözlü ve uzun boylulardır. Kırgızların bu ilk devletlerini kurdukları dönemler bugünkü Kırgızistan topraklarından doğuya ve kuzey doğuya uzanan Orhon sahasından Hakasya'ya kadar olan bölgede yaşadıkları, sonra da Hunların hâkimiyeti altına girdikleri belirtilmektedir. Çin kaynaklarının yanı sıra Orhun'daki Türk yazıtlarında da Kırgızlarla ilgili bilgiler bulunmaktadır.

Adlarının etimolojisi hakkında çeşitli bilgiler öne sürülmüş olan Kırgızlar, Çin tarihi kaynaklarında "Gengün" ve "Hia-kia-sseu" şeklinde geçmektedirler (Kafesoğlu, 1992: 150). Çin dilinde bu kelimenin karşılığının "Kırgız” olduğu söylenmektedir. Kırgızlar, kaynaklarda Türk asıllı olarak gösterilmektedir. Divanü Lugati't Türk'te "Gırgız” bir Türk boyunun adıdır denilmektedir (Mahmûd - el - Kaşgarî, 2007: 427).

XVI - XVII. yüzyıllarda Kalmuk ve Moğollara karşı mücadele veren Kırgızlar, XVIII. yüzyılda Türkistan'da teşekkül eden hanlıklara tabi olmuşlardır. 1860 - 1861 yıllarında Ruslar tarafından toprakları işgal edilmiş olan Kırgızlar, Sovyetler Birliği’nin dağılmasıyla 1991 yılında tekrar bağımsızlıklarına kavuşmuşlardır.

Kırgız tarihi genel itibariyle esas olarak şu dönemlere ayrılmaktadır:

- Göktürk Dönemi

- Uygur Dönemi

- Timur ve Hanlıklar Dönemi

- Rus Çarlığı Dönemi

- S.S.C.B. Dönemi

- Bağımsız Kırgız Cumhuriyeti

\section{Yüzyılın İkinci Yarısında Türkistan'ın Durumu:}

Tarihte uzun yollardan geçen Kırgızlar, XIX. yüzyılın sonlarına doğru Çarlık rejiminin yönetimi altında yaşamaya başlamışlardır. Doğrusunu söylemek gerekirse Sovyetler Birliği dağılana kadar, Çarlık yönetimiyle ilgili değişik fikirler söylenmekteydi. Bunlardan biri de "Kırgızlar, Çarlık Rusya’sına kendi istekleriyle dâhil olmuşlardır” şeklinde sunulan ve uzun 
yıllar devam eden; tarih, edebiyat kitaplarında yer alan ve öğretilen politikadır. Ancak Sovyetler Birliği’nin dağılmasıyla beraber Kırgızistan'ın bağımsızlığını alması, bizim bildiğimiz bu bilgilerin gerçeğe hiç uymadığını göstermektedir. Gerçek şu ki; Çarlık Rusya'sı XIX. yüzyılın ikinci yarısında Türkistan'a zorla girmiş ve burayı işgal etmiştir. 1867 yılında Rus Çarı tarafından Türkistan'a general - vali tayin edilmiş ve o topraklar önce bölgelere sonra da eyaletlere bölünmüştür. Bu görevi yapanlar Polonya'daki, Kafkasya'daki halk isyanlarını yöneten ve acımasızca bastıran M. G. Çernyayev, S. V. İvanov, M. D. Skobelev, A. N. Kuropatkin gibi tecrübeli generallerdi (Moldokasımov, 2012: 55). Adı geçen generaller Kırgız topraklarını iyice incelemişler; kendi milletlerinden olanları Kırgızistan'ın sulu, verimli topraklarına, sıcak bölgelerine yerleştirmişlerdir. Örnek verecek olursak, 1868 -1892 yılları arasında Türkistan'ın verimli topraklarında yüzden fazla Rus köyü kurulmuştur (Moldokasımov, 2012: 56).

Bu durumu dönemin şairi Arstanbek, "Dar Zaman” manzumesinde şöyle anlatmaktadır:

Almatıdan attanıp,

Orus kele catır ay.

Uzun çöptün baarısın,

Orup kele catır ay.

Kıska çöptün baarısın,

Korup kele catır ay.

Bul orustu karasan,

Enci kılıp cerdi aldı.

Beeden tuugan kerdi aldı.

Kardı salık baydı ald1,

Kaça turgan caydı aldı.
Almatı' dan atlanip,

Rus buraya geliyor.

Uzun otun hepsini,

Toplamaya geliyor.

Kisa otun hepsini,

Korumaya geliyor.

Bu Rus'a göz atsan,

Sahiplenip toprağ aldı.

Kısrağın doğurduğu tayı aldı,

Göbeği büyük bayı aldı,

Kaçacak yerimizi aldı (Arstanbek, 1990: 36).

Çarlık Rusya'sı yönetim amaçlarına ulaşmak için yerli zenginlerle arasını iyi tutmuştur. Böylece her geçen gün Kırgız topraklarına yerleşen Rus sayısı artmıştır. Halk, hem yerli zenginler hem de Rus zenginleri tarafından ezilmiş; onların her türlü işini yapmış; yaptığı işlerin karşılığında ise tam olarak haklarını alamamıştır. Bu durumla ilgili fikirlerini Arstanbek, "Dar Zaman" manzumesinde şöyle devam ettirir: 
Karagaydın tanında,

Elik boldu elibiz.

Kaptagan tuzdu kötörgön,

Kölük boldu elibiz.

Başka çapsa bılk etpes,

Ölük boldu elibiz.

Uşul zaman tar zaman,

Azuularga bar zaman,

Beçaraga zar zaman.
Sabahın ilk vaktinde,

Geyik oldu halkımız.

Çuval çuval tuz taşıyan,

Köle oldu halkımız.

Başına vursa seslenmez,

Ölü oldu halkımız.

Bu zaman dar zaman,

Dişlilere var zaman,

Biçareye zor zaman (Arstanbek, 1990: 39).

Dönemin yaşamına şahitlik eden Arstanbek'in bu manzumesine baktığımızda Çarlık Rusya’sının sömürgeci ve baskıcı politikasının nasıl gerçekleştiğini açıkça görebiliyoruz.

Yine dönemin şairlerinden Moldo Kılıç, "Zor Zaman” manzumesinde "Rus" kelimesinin yanı sıra "kâfir” kelimesini de kullanmıştır. Şair, manzumesinde "Müslüman’ın sorgusu yine kâfir elinde", "Rus kâfiri kurnazdır, her silahı hazırdır", "Nerden bilsin bu kâfir, Kazak, Kırgız halkını. Kayda aldı gördün mü, kadın, çocuk hepsini. Askere alır gerektiğinde, yakalayıp çocuğunuzu” (Moldo Kılıç, 1990: 74) diyerek gördüklerini açıkça dile getirmiştir. Şair, şiirlerinde sadece Rus Çarlığının yaptıklarını anlatmakla kalmayıp yerli zenginlerin de halk1 nasıl sömürdüğünü, nasıl ezdiğini dile getirmiştir.

P. P. Semenov'un "1856 - 1857 Yıllarında Tanrı Dağlarına Gezi" adlı çalışmasına bakacak olursak her şey açıkça anlaşılacaktır. P. Semenov'un yazısının özeti şöyledir:

Benim, İli'nin arka tarafındaki toprakları alma ve sömürgeleştirme fikrim Gasrtof'un hoşuna gitti. Devlet sınırının Kırgız topraklarının ön tarafından geçmesi gerektiğini söylediğimde heyecanlandı. Önümüzdeki çok yakın zamanda bizim devlet sınırımızın, Vernıy ile Isık Göl'ün batısını birleştirmesi gerektiği fikrimi Albay Obuhanov'a da söylemeye karar verdim. Çünkü istihbarat elde etmek ve böyle bir bölgeye sahip olmak için çok yakında bir gezi heyeti oluşturmak gerekiyor. Bu en doğru fikirdi. Bu topraklarda sağlam ve bozulmaz sınır kurmamız lazım. Bunun için de Bugu boyunu tez zaman içinde kendimize dâhil etmemiz lazım, onların peşinden de Sarıbagış boyunu. Böylece Rus devlet sınırları, Isık Göl bölgesinin tamamını almak suretiyle, Tanrı Dağlarının beyaz karlı tepeleri ile birleşir ve İli topraklarının tamamını almak, daha da kolaylaşır. Ayrıca Çüy bölgesindeki noktalara sahip olmak için de anahtar rolü oynar (Artıkbayev, 2004: 348).

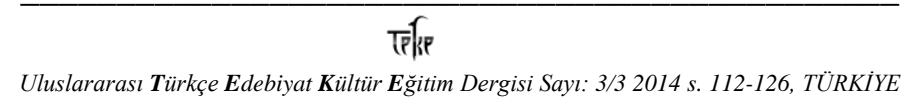


Gördügümüz gibi bu özetten da anlaşılacağı üzere P. P. Semenov'un "bilimsel gezi" bahanesi ile gelmesinin altında yatan asıl amaç; Kırgız topraklarında keşif yapmak ve onu kolonileştirmeye hizmet etmekti.

\section{İsyanın Çıkış Sebepleri ve Ürkün:}

İlk olarak Rus - Japon Savaşından sonra, I. Dünya Savaşı başlamış ve tüm harcamalar halktan vergi adı altında toplanmıştır. Bunca sömürüye, acıya dayanamayan Kırgız, Kazak halkı 1916 yılında millî mücadele başlatmıştır. Aslında mücadelenin en önemli sebeplerinden biri, çok sayıda Rus çiftçisinin o topraklara gelmesi ve onların yerleştirilmesinde Kırgızlara yani yerli halka karşı zor kullanılmasıydı. Mesela, Rus çiftçilerini merkezden taşıma işinde 1896 1916 yılları arasında, 237.310.236.00 (iki yüz otuz yedi milyon üç yüz on bin iki yüz otuz altı) ruble harcanmıştır. 1916 yılında Türkistan'da genel halkın yüzde altısını oluşturan Rus milletine, işlemesi için en verimli toprakların yüzde 57,7'si verilmiş, halkın yüzde doksan dördünü oluşturan yerel halkın payına ise toprağın yüzde 42,3’ü düşmüştür (Kazıbaev, 1996: 102). Ayrıca Rus çiftçileri yerli halkı insan yerine koymamış, aşağılamış, suyun başını sahiplenmişler, Kırgızlara su vermeyip onları topraklarını bırakıp gitmeye mecbur bırakmışlardır. Bunlarla beraber yerli halkın dinî inançları gibi hakları da sınırlanmış ve Kırgızistan topraklarına Rus isimleri verilmeye başlanmıştır. Amaçları yeni Rusya yaratmak olmuştur. Buna örnek olarak Andijan'da 1898 yılında gerçekleşen ve çoğunluğunu Kırgızların oluşturduğu isyanı verebiliriz. Bu isyanı yöneten 45 yaşındaki Madalı isimli Kırgız'dı. Madalı, bu isyanın sebebini şu şekilde açıklamıştır: "Ruslar insanlarımıza içki içmeyi öğretiyorlar. Cami, medreseleri kapatıyorlar. Dinimize baskı uyguluyorlar. Buna dayanmak mümkün değil.” (Moldokasımov, 2012: 58). Bu ayaklanma Madalı'nın ölümüyle ateşlenmiş; fakat acımasız bir şekilde bastırılmıştır.

Ancak Kırgızların bu durumdan rahatsız olduklarını da hissetmişlerdir. Örneğin; Türkistan bölgesinin general - valisi A. N. Kuropatkin Rus çarına yazdığı bir mektubunda şöyle demektedir: "Kırgızlardan topraklarının en verimlilerini aldıkça huzursuzluk daha da artmaktadır. Eninde sonunda onların da millî duyguları uyanır ve bu topraklara yerleştirilen Rus halkı ile farklı olduklarını anlarlar. Bundan dolayı Kırgızların toprak meselesini çözmemiz lazım" (Soltonoyev,1993: 92). A. N. Kuropatkin, bu meseleyle Rus Çarına sıkça başvurmuş; ancak hiçbir sonuç alamamıştır. Sorunları çözmenin aksine, Rus Çarlığı yöneticileri arasında ayaklanmanın şiddetli bir şekilde gerçekleşmesini isteyenler de vardı. Onlara göre Kırgızlar başkaldırıp isyan ederse, daha çabuk ortadan kaldırılacak ve böylece boşalmış topraklara Rus halkı yerleşecekti. 
1914 yılında başlayan I. Dünya Savaşı ve bu savaşta Rusya’nın da yer alması, zaten zor bela yaşayan halk için hiç iyi olmamıştır. 1916 yılının Haziran ayında, Rus çarının, Türkistan halklarından savaşa katılabilecek 19 ile 43 yaşları arasındaki erkeklerin askere alımı yasası çıkmıştır. Bu yasa, yukarıda adı geçen halk şairi Moldo Kılıç'ın "Kayda aldı gördün mü, kadın, çocuk hepsini. Askere alır gerektiğinde, yakalayıp çocuğunuzu" diyerek kaygılanmasının ta kendisiydi. Bu yasa; zaten ezilmiş, aşağılanmış ve topraklarından olmuş halkın isyan etmesine neden olmuştur. Çarın bu yasası üzerine alınmış emre göre Türkistan'ın Sır Derya bölgesinden altmış bin, Semerkant bölgesinden otuz iki bin beş yüz, Fergana bölgesinden elli bir bin üç yüz, Yedi Su bölgesinden ise kırk üç bin kişi askere alınmıştır. Ayrıca asker yasasına göre askere alınacak insanların kendilerine sıcak giysilerini, birkaç gün yetecek kadar erzakını ve belirli bir miktarda parasını da hazırlaması gerekirdi. Asker yasasının haziran ayında çıkması ve erkeklerin bu ayda askere alınması tarla işlerini de aksatmıştı. Zaten fakir yaşayan halk daha da zorda kalmıştı (Moldokasımov, 2012: 76). Bu duruma dayanamayan ve önceden de hep ezilmiş olan halk, millî mücadele için hazır hâle gelmiştir. Kırgızistan'ın kuzey bölgesindeki millî mücadele, Türkistan'ın diğer bölgelerinden farklı olarak şiddetli bir şekilde geçmiştir. Bu mücadeleye Kırgızlar ile beraber o bölgede yaşayan Kazak, Uygur, Çin Müslümanları da katılmışlardır. Halk toplanıp kendi arasında savaşa asker vermeme kararı almıştır. Mücadele ilk olarak temmuz ayında başlamış ve ağustos ayında şiddetlenmiştir. Kuzey Kırgızistan'dan ilk olarak Kemin bölgesi çıkmış ve gelenek görenek, örf adetlerine uygun bir şekilde kendilerine lider olarak Möküş Şabdanoğlu'nu seçmiştir. Sonra da Tokmok'un etrafındaki tüm köylüler çıkmış ve kendilerine lider olarak Ibırayım Töloğlu'nu seçmiştir. Mücadeleye Tanrı Dağlı (Narın) Kırgızlar da aktif bir şekilde katılmışlardır. Koçkor bölgesi bu isyanın merkezi olmuştur. Mücadeleciler kendilerine lider olarak Kanat Ubukeoğlu'nu seçmişlerdir (Moldokasımov, 2012: 63). Kanat Ubukeoğlu yönetimi altında toplanmış askerler, Rusların yaşadığı çeşitli köyleri ateşe vermişler; yağmalamışlardır. Çarın askerlerinin elinde her çeşit silah vardı; Kırgızların ellerinde ise tüfekler, ağaçlardan yapılııı mızraklar ve baltalar bulunmaktaydı. Hayatları boyunca göçebe hayat tarzını benimsemiş olan Kırgızlar, o dönemler hem Ruslar kadar savaş taktiklerini bilmiyorlardı hem de ellerindeki silahlar Ruslarınkine göre elverişsizdi. Fakat tüm bunlara rağmen Kanat'ın adamları Almatı'dan gelen bin altı yüz civarında çar askeri ile yüz yüze gelmiş, savaşmış, mücadele etmiş ve çoğu da ölmüştür. Ayaklanma Kırgızistan'ın tüm bölgelerine sıçramıştır. Bu ayaklanmaya genel olarak on milyondan fazla insan katılmış, yüz binden fazla insan ölmüştür (Kazıbaev, 1996: 3). Bundan dolay1 1916 yılının 17 Temmuzunda Türkistan'da olağanüstü durum ilan edilmiş ve Türkistan'a on bir tabur, üç bin civarında Rus askeri gönderilmiştir. Onlar, çok sayıda top ve makineli tüfek ile silahlanmışlardı. Kısacası Türkistan'ın çeşitli bölgelerinde çıkan isyanı, savaş taktiklerini iyi

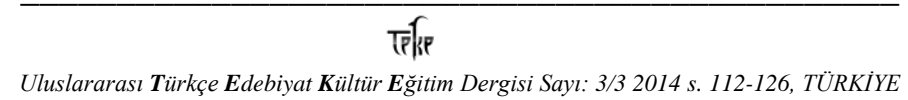

International Journal of Turkish Literature Culture Education Volume 3/3 2014 p. 112-126, TURKEY 
bilen ve gelişmiş silahları olan Rus askerleri acımasız bir şekilde bastırıyorlardı. Mesela, Çüy bölgesinin Belovodsk şehrinde beş yüzden fazla Kırgız'ı mücadeleye katıldıkları bahanesiyle acımasız bir şekilde öldürmüşlerdir. Buna örnek olarak, Vernıy bölgesinin komutanı Basilevkiy'in 11 Ağustos'ta verdiği açıklamasını ve Isık - Göl bölgesinin asker valisi Folbaum'un Kuropatkin'e yazdığı mektubu verebiliriz. Basilevskiy açıklamasında şöyle diyor: "Şimdilik Ak - Su (Isık - Göl) bölgesi sakin. 3Ağustosta ayaklanan Kızılbörk kabilesinin cezasını verdik.” (Kazıbaev, 1996: 96). Folbaum'un, Kuropatkin'e yazdığı mektubunda ise şöyle diyor: "Bundan sonra Kırgızların şartlarını daha da ağırlaştırmak gerek. Dolayısıyla ayaklanmaya katılamayacaklardır. Son zamanlarda büyük başarılara ulaşılmıştır: Iısk - Göl'ün kuzeyinden ve Prejevalskiy'in etrafındaki isyancıların yarısı topraklarını bırakıp Narın'a gitmeye mecbur kaldılar. Çüy ile Son - Köl'deki isyancılar da Cumgal ve Koçkor'a sürüldü. İsyancılardan alınan hayvanlar, onların yenilgisinin işareti olmuştur. Prejevalskiy'de üç yüz binden fazla hayvan toplandı.” (Kazıbaev, 1996: 98). Çünkü P. Rumyantsev'in o dönemdeki araştırmasına göre Isık - Köl bölgesinde 57.126 hektar ekin tarlası, 46.288 hektar hayvanları otlatma tarlası, 1836.309 hektar kışlak için tarlası, 2.815.400 hektar yazlık tarlası, toplam 4.755.122 hektar toprak vardı. Amaç bütün bu topraklara Rusları yerleştirmek idi (Kazıbaev, 1996: 102). Görüldüğü gibi ayaklanmaya katılan Kırgızları yaşam şartları ağır olan Narın’a sürmüşlerdir. Narın o dönem için tam bir sürgün yeri olmuştur.

Kendisi Çin'de yaşayan Kırgız bilim adamı A. Baytur 1992 yılında Kırgızistan’da basılmış olan Kırgız Tarihinin Dersleri adlı kitabında yer alan "Kırgızların Rusya'ya Karşı Mücadelesi” adlı başlığında bu isyanı şöyle değerlendirmiştir: "Rusya'nın baskısı altında kalan Kırgız halkı, savaşa ve asker alımına karşı isyan etti. 1916 yılının yedinci ayında Kırgızistan'ın güney bölgesi, 8 - 9 aylarında ise Bişkek, Karakol, Talas Kırgızları ayaklandı. Ancak Rusya hükümeti sayısız asker gönderip Kırgız bölgelerini kana boyadı” (Cakıpbekov, 2012: 51).

$\mathrm{Bu}$ durum diğer köylerde de devam ediyordu. Eylül ayına gelince çarın askerleriyle ufak tefek çatışmaların dışında büyük olaylar sona ermiş, genellikle millî mücadele başarısızlıkla sonuçlanmıştır. Silahsız halkın büyük mücadelesi esnasında çok sayıda insan ölmüştür. Bu duruma dayanamayan Kırgızlar, Ata Yurdunu bırakıp Çin'e kaçmışlardır. Bu kaçış aslında Kırgızlar için bir soykırımdan kurtuluştu. Çin malumatlarına bakacak olursak Çin'e Kırgızistan'dan 332 bin insan kaçmış, Kuzey Kırgızistan halkının sayısı yüzde 41,4 oranında azalmıştır. Bu olay tarih sayfalarına "Ürkün” adıyla silinmeyecek şekilde yazılmıştır. 1916 yılında Kırgızların yaşadıkları bu zor günler halk ağzında "Ürkün” adıyla anılmaktadır. Günümüzde "ürkmek" kelimesi daha çok hayvanlar için kullanılarak, sınırlanmış durumda olsa da Divanü Lugati’t Türk’te “Ürkti” ve “Ürkün” kelimeleri şu şekilde açıklanmıştır: goy ürkti: 
Koyun (gece ya da gündüz, kurt ya da benzer bir şey nedeniyle) ürktü; bodün ürkti: Düşmanın ortaya çıkmasıyla birlikte halk ürktü ve dehşete kapıldı; Ürkün: Düşmanın yaklaşması nedeniyle halkı saran ve kalelere ve hisarlara kaçmalarına neden olan dehşet ve korku (Mahmûd - el - Kâşgarî, 2007: 638).

Ancak Çin'e kaçmak da kolay olmamıştır. Kaçış, sonbahar mevsimine denk geldiği için halk çok zor günler yaşamıştır. Kardan dolayı geçitten geçmek zor olmuş; halk eşeklerini, atlarını, katırlarını keserek sıcak postunu buzlu yerlere serip onların üstüne basarak kaymadan yürümeye çalışmıştır. Bu durum hayvanların azalmasına neden olmuştur. Sadece bir geçitten geçmek için çok sayıda büyük baş hayvanlarından ayrılmışlardır. Hem soğuktan hem açlıktan Çin'e ulaşamadan çok sayıda insan ölmüştür. Sınırı geçince de yiyecek olmadığından kalan hayvanları telef olmuştur. En önemli varlıkları hayvan olan, geçimini hayvanlarla sağlayan Kırgızlar, tüm hayvanlarını kaybedince çok fakirleşmiştir. Çin'e kaçan yani Çin'e ulaşan halkın çileli hayatı orada da devam etmiştir. Çünkü orada Uygur ve Çin zenginlerine sırf karınlarını doyurabilmek için kapı hizmetçisi olarak çalışmışlardır. Kaçıp gelen halkın zor durumundan istifade eden Çin ve Uygur zenginleri, Kırgızların on beş - on altı yaşlarındaki kızlarına göz dikmiş; onlara zorla sahip olmuşlardır. Zorda kalan aileler bir kâse un, kavut için kızlarını Çin ve Uygur zenginlerine vermek zorunda kalmışlardır. Bu sırada yaşanan acılı olaylar, yukarıda da anlatıldığ gibi zamanın halk şairleri tarafından dile getirilmiştir. Bu eserlerden biri de Isak Şaybekov'un "Kayran El” (Gariban Halk) manzumesidir. "Gariban Halk" manzumesi daha 1916 yıllarında halk tarafından geniş bir şekilde biliniyor ve seviliyordu. İsak Şaybekov manzumesinde 1916 yılındaki “Ürkün”ü şu satırlarla anlatmıştır:

$\begin{array}{ll}\text { “Cüktöp alıp eşekti, } & \text { Yükleyerek eşeğini, } \\ \text { Ceteledi kayran el. } & \text { Çekti gitti, gariban halk. } \\ \text { Arzan şaar kayda dep, } & \text { Ucuz şehir nerde diyerek, } \\ \text { Tötölödü kayran el. } & \text { Arayıp durdu gariban halk. } \\ \text { karıları basa albay, } & \text { Yaşlıları yürüyemeyip, } \\ \text { Cötölödü kayran el. } & \text { Öksürüğe kapıldı, gariban halk. } \\ \text { Caş baldarın moynuna, } & \text { Küçük çocuklarını omuzda, } \\ \text { Kötörödü kayran el. } & \text { Taşıyıp gidiyor, gariban halk. } \\ \text { Karangı Uygur tamında, } & \text { Uygur'un karanlık evine, } \\ \text { Korgolodu kayran el. } & \text { Başını soktu gariban halk. }\end{array}$


Baarın berip can üçün,

Her şeyini verip yaşamak için,

Corgolodu kayran el.

Yola çıktı gariban halk.

Cazgı camgır moynuna,

Bahar yağmuru başından,

Şorgolodu kayran el.

Döküldü, durdu gariban halk.

Çını menen oşentip,

Gerçekten de hep böyle,

Kor bolobu kayran el.

Horlanır mı gariban halk.

Topolonu toz bolup,

Darmadağın olarak,

Tozup ketti kayran el.

Saçıldı şimdi gariban halk.

Öz elinen adaşıp,

Öz yurdundan ayrilıp,

Bozup ketti kayran el.

Kaçıp gitti gariban halk.

Ala kiyiz töşök cok,

Döşeği yok, yatak yok,

Cerge cattı kayran el.

Yere yattı gariban halk.

Aks1, Turpan siz ceri,

Aks1, Turpan soğuk yer,

Belge batt1 kayran el.

Bele battı gariban halk.

Kiyim, tamak taba albay, Giysi, yemek bulamayı,

Aldıradı kayran el.

Güçsüz kaldı gariban halk.

Ar kimge tam bergin dep,

Yabancidan yardım isteyip,

Caldıradı kayran el.

Aşağılandı gariban halk.

Çoguluşup ölgönün,

Toplanıp ölenlerini,

Kömüşpödü kayran el.

Defnedemedi gariban halk.

Kazan, ayak, tabaktar,

Kazan, kâse, tabaklar,

Üyün sattı kayran el.

Evini sattı gariban halk.

Üygö ciygan töşönçü,

Evindeki yorgan1,

Cügün sattı kayran el”.

Her şeyi sattı gariban halk (Şaybekov, 1993: 126).

O dönemler henüz çocuk yaşında olan yazar ve şair Aalı Tokombaev, I. Şaybekov'un "Gariban Halk" manzumesi ile ilgili anısını şöyle anlatır:

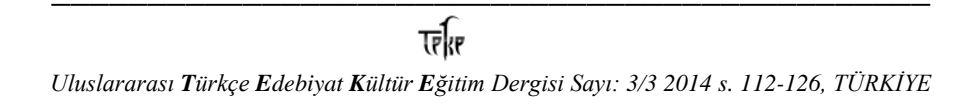


1917 yılından 1919 yılııın ortalarına kadar Kuzey Kırgızistan'ın birçok yerinde dilencilik yaparak yaşamak zorunda kalmıştım. Dilenciler genelde ellerini uzatarak "Allah rızası için" derlerdi. Ben bu cümlenin anlamını bilmediğimden değil de avuçlarımı açıp elimi uzatmaktan utandığım için hiçbir şey yapmadan Isak Şaybekov'un millî mücadeleyle ilgili manzumesi "Gariban Halk”1 söyleyiverirdim. Aslında böyle bir şey yapmak benim buluşum değildi. Bekturgan isimli bir dilenci ihtiyar keşfetmişti. O ihtiyar, ilkbaharda benim karşıma çıkmış ve peşime takılmıştı. Böylece benim söylediğim "Gariban Halk" manzumesi ikimize ölmeyecek şekilde yaşamamız için azık bulmamızda işimize yaramaya başlamıştı (Artıkbayev, 2004: $39)$.

İsak Şaybekov “Ürkün”ü anlatan "Gariban Halk” manzumesinin devamı olarak “Azgan El” (Kaçan Halk), “Kaytkan El” (Dönen Halk) isimli manzumelerini de yazmıştır.

Ürkün'ün gerçeklerini anlatmak için dönemin halk şairi Aldaş Moldo da çabalar göstermiştir. Bunu, şairin “1916 Y1lındaki Ürkündön Murda” (1916 Yılındaki Ürkün'den Önce), "Ürkün” (Ürkün), “Altı Şaar” (Altı Şehir) adıyla yayımlanan eserlerinden anlayabiliriz. Şair "1916 - cılkı ürkündün aldında” (1916 Yılındaki Ürkünden Önce) adlı manzumesinde "Çarlık Rusya'sı yerli halktan asker alacakmış" haberini duyunca zenginlerin kendi çocuklarının yerine çeşitli bahanelerle fakirlerin çocuklarını kayıt ettirdikleri anlatılmıştır. Mesela; Kulbarak adlı bir zengin bey, oğlu Baycumaş'ın yerine yanında çalışanı Sıdık'ın oğlu Osmon'u askere yazdırmıştır. Bunu duyan Osmon’un annesi Ayımkan'ın gözyaşları sel olur. Mamırbay isimli bey, oğlu Asanku'u askere göndermez ve onun yerine yoksul bir adam olan İtibay'ın oğlu Makeş’i yazdırır (Aldaş Moldo, 1990: 199). Aldaş Moldo, eserlerinde o dönemin adaletsizliklerini dile getirir.

Yukarıda adı geçen eserler, 1947 - 1989 yıllar arasında Komünist Parti yöneticileri tarafından yasaklanmıştır. Adı geçen şairler "gerici şairler" olarak değerlendirilmişler ve "kara insanlar" olarak tarihimizden uzaklaştırılmışlardır.

O dönemi yaşayan ve halkla beraber Çin'e kaçan yazarlardan biri de K. Bayalinov'dur. Yazar, Kıyın Ötkööl (Zor Günler) adlı eserinde kendi özgeçmişinden başlayıp, sanat hayatına kadarki dönemleri sırasıyla anlatmaya çalışmıştır. Eserde, yazar Ürkün'den önce Sakıp Camal isimli bir kıza âşık olduğunu, o kızın onun ilk göz ağrısı olduğunu anlatır ve "o zaman ben on altıdaydım, o on beşteydi” diye anar. Yazarın sevdiği kız Sakıp Camal on beş yaşındayken elli yaşını geçmiş bir zengine satılır. Yazar bir anısında "ben o zaman Kırgız kızlarının yaşadığı zor günleri, ağır kaderi yazmayı amaç edinmiş̧tim” der. Aslına bakacak olursak 1916 yılında Çin'de yoksulluktan dolayı ailesi tarafından satılan çok sayıda Kırgız kızı olmuştur. Bunların hepsini 
K. Bayalinov kendi gözleri ile görmüştür. Yazar, bütün gördüklerini “Tyan Şan Cazı” (Tanrı Dağları Baharı) ve "Unutulbas Kündör" (Unutulmaz Günler) adlı hatıralarında etraflıca anlatmıştır. Mesela, yazar Çin'e geldiğinde, Üç Turpan'da Sabitahun isimli bir zenginin işlerini yapar. İşte orada Kırgızistan'ın Koçkor bölgesinden gelen Bobugul isimli adamın sırf karınlarını doyurabilmek için kızını Sabitahun'a sattığını görür. Sonra o kızı daha zengin Nurahun isimli birinin satın aldığını görür. Açgözlü paragöz Sabitahun, Nurahun'un teklif ettiği parayı geri çevirmeyip güzel ve genç kızı ona satar. Kısacası ölmemek, karınlarını doyurmak için Çin ve Uygur zenginlerine satılan sadece Sakıp Camal değildi. Anlaşıldığı üzere daha çoktu. Yazarı yaralayan bu olaylar, sonradan onun "Acar" adlı uzun hikâyesini yazmasına neden olmuştur. Eserde Acar isimli on beş yaşındaki Kırgız kızı, Çır isimli yaşlı, zengin Çin tüccarına satılır. Çır'a üçüncü hanım olarak alınan Acar, her gece yatak odasında Çır'ın gelmesini korkuyla bekler. On beş yaşına yeni girmiş Acar, kocası olan Çır'ı korkuyla beklerken kendisi gibi satılan Ayganış'ı, Saarkan'ı hatırlar. Zenginliği ile tanınan, nankör, merhametsiz, bencil Çır'ın tek amacı ise gencecik kızı koynuna almak.

Ancak, Acar hep bir gün gelir de serbest kalırım diye hayal eder ve bir mayıs gecesi Çır'ın evinin avlusundan yavaşça kaçıp gider. Yazar, o geceyi şöyle anlatır:

Mayıs ayının son günleri. Gece. Gökyüzü masmavi. Boncuk gibi dizilmiş yıldızlar birbirlerine bakıp göz kırpıyor gibiler. Tabiata ait ne varsa mayıs ayının bu huzurlu ve serin gecesinde uykuya dalmış. Fakat kıbleden gelen serin rüzgâr, ağaç yapraklarını yavaşça sallayıp ses çıkartıyor. Uzaktan gelen bekçi sesi ile yaprak sesleri birbirine karışıyor. Mayıs ayının bu gecesinde serin bir rüzgâr esti. Gökyüzündeki ak bulutlar yavaş yavaş uçmaya devam ediyorlar. Rüzgâr onları gözükmeyen sevimli kolları ile Tanrı Dağlarına doğru itiyor. Kaşkar'ın ıssız tarlasını karanlığa boğuyor (Bayalinov, 1983: 20).

Kısacası, Acar'ın ölümüne karanlık gecede karşısına çıkan aç kurtlar neden olur. Baktığımızda sadece "Acar" hikâyesi değil, o dönem yazılmış eserlerin çoğu o yılların acı gerçeklerini anlatmaktadır. Çünkü o dönemi yaşayan şair ve yazarların kalbinde iyileşmez bir yara olarak kalmıştır.

O dönemi yaşayan şair ve yazarlardan biri de Aalı Tokombayevdir. Yazarın daha önceleri okunması ve okutulması yasaklanmış olan ve 1991 yılından itibaren tekrar yayımlanan eseri Kanduu Cildar (Kanlı Y1llar) unutulacak, bir kenara atılacak eser değildir. Eser, 1962 yılında Tan aldında (Şafağa Doğru) adıyla kısaltılarak ve düzeltilerek yayımlanmıştır.

Yazar Kanduu Cıldar (Kanlı Yıllar) eserinde Kırgızların 1916 yılındaki ayaklanmasını, Çin'e kaçışını, dönüşünü, kısacası Kırgızların çileli hayatını, bununla beraber Kırgız halkının 
bilgeliğini, akıllılığını, insanc1llığını, kahramanlığını, dayanıklılığını, söz ustalığını, merhametliliğini, hassaslığını, aynı zamanda da çok şeyden geri kalmışlığını ustalıkla anlatır. Çarlık döneminde halkın çektiği eziyet, verginin artması, halkın kendi topraklarından dağlara sürülmesi ve çocuklarının askere alınacağını duyan halkın çaresizliği eserin ana konusudur. Eserde halkın durumu "dağlardan seslenen geyikler", "korkudan yoncalara saklanan tavşanlar", "gazaplı dağları mekân edinen geyikler" (Tokombayev, 1991: 13) şeklinde tarif edilir.

Çarlık Rusya’sının Kırgız topraklarını nasıl işgal ettiğini anlatan önemli eserlerden biri de Tölögön Kasımbekov'un Singan Kılıç (Kırılan Kılıç) eseridir. Kırılan Kılıç eseri, Kırgız edebiyatındaki ilk tarihî romandır. Bu eserde 1842 - 1876 yılları arasındaki kısacası XIX. yüzyılın ortası ile ikinci yarısında Kırgızların hayatı, Hokand hanlığı dönemindeki saray halkı ile normal halkın siyasi, sosyal, ekonomik, birbirlerine zıt gelişen hayatı ve bunun yanı sıra Kırgızistan'ın Çarlık Rusya'sı tarafından acımasızca işgal edilişi anlatılır. Eserde adı geçen insanların çoğu (Çernyayev, Skoblev, Alımbek, Alımkul, İshak vb.) tarihte yaşamış insanlardır ve onların yaptıkları işler tarihte bilinmektedir. Eser, Çarlık Rusya'sı generali Çernyayev'in çeşitli top ve silahlarla yaptıkları eğitimi ve beş yüz kadar seçilmiş askeri ile Hokand hanlığına karşı savaşmalarıyla başlar. Eserdeki bu olaylar sonradan Skobelev'in günahsız halkı ok yağmuruna tutmasıyla devam eder. Halkın arasından sakalı beline kadar gelen yaşlı bir adam Skoblev'in isteği üzerine öldürülmeden sağ bırakılır, başkaları tamamen öldürülür. Oysa Skobelev'in amacı yakılıp yok olan köyde yaşlı adamı, yalnız bırakıp onu zorda bırakmak idi. Sırada Maası köyü vardır. Oradakileri de bir insan bile bırakmadan kırarlar. Tahminen sekiz, on yaşlarındaki üç çocuk kaçarken onları Krivinsov adlı asker kovalar ve vurur. Bunları gören oryantalist, General Skobelev'e "Mihail Dmitreviç Skobelev bu nasıl iş? Silahsız halkı öldürmek, küçük çocukların peşinden kovalayıp vurmak, medeni, gelişmiş ülkelerin yapacağ 1 iş değil. Tüm gelişmiş ülkelere rezil oluruz. Küçük çocukların peşinden gidip öldürmek felakettir. Krivinosov cezalandırılsın", der. Bunu duyan M. D. Skobelev ise "Rusya'ya başını eğmeye ikna olmayan cahil Asyalının cezasını vermeyelim mi?” (Kasımbekov, 1998: 601) diye cevap verir. Okuyucu bu tarihî romanı okuduktan sonra tarihî bir gerçeği anlamış olur. Eserde Rus Çarlı̆̆g, kendilerine yakın olmak isteyen zengin beyleri kandırıp onların yardımıyla, çeşitli kurnazlık ve hileleriyle Kırgız halkını kendilerine boyun eğdirdikleri açıkça anlaşılmaktadır. Yazar Tölögön Kasımbekov, Kırgız halkının en önemli tarihî dönemini, Rusya'nın Kırgızistan'ı kendine bağladığı zamanı, bu dönemde halkın yaşadığı zor günleri bu şekilde eserleştirmiştir. Kırgız edebiyatında, Rusya'nın Türkistan topraklarını işgal etmesi ve 1916 yılındaki isyanı anlatan çok sayıda eser vardır. Onların hepsinden örnek vermek mümkün değildir. Ancak biz birkaçından örnek vermekle yetineceğiz.

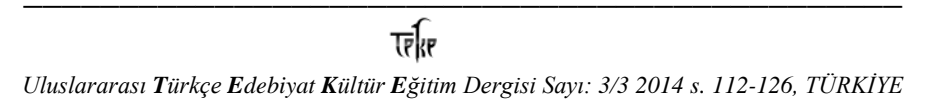


2011 yılında Kırgızistan'da Ürkün'ün 95'inci yıl dönümü anısına bir tören gerçekleşmiştir. Profesör Kıyas Moldokasımov'un bu törendeki beyanında şu bilgiler yer almaktadır: "Arşivdeki korunan belgeler arasında "Ürkün" belgelerinin yeri çok farklıdır. Kazakistan Cumhuriyeti Merkezi Devlet Arşivi’nin 44 numaralı ve Özbekistan Cumhuriyeti'nin başkenti Taşkent şehrinde bulunan merkez arşivinin 246 numaralı kayıtlarında verilen bilgiler aynıdır. Belge, "Türkistan valisi, generali A. N. Kuropatkin'in yönetimi altında 16 Ekim 1916'da gerçekleştirilen, 1916 yılında ayaklanmaya katılan Kırgız ve Kazak halklarının Narın’a sürülmesi ve onların topraklarının Rusya'dan gelen çiftçilere verilmesi ile ilgili toplantının tutanağı" diye adlandırılmaktadır. Toplantı, Yedi Su bölgesinin başkenti Alma Ata şehrinde gerçekleşmiştir. Bu toplantıya general - vali A. N. Kuropotkin ile Yedi Su eyaleti asker valisi M. A. Sokolov - Sokolinskiy başta olmak üzere 13 üst düzey görevli katılmıştır. Bu insanlar adı geçen toplantıda Prejevalsk (Karakol), Pişpek (Bişkek) bölgelerinde gerçekleşen ayaklanmaları incelemişler ve ayaklanan insanların hayatlarıyla ilgili kararlar almışlardır. Toplantının birinci oturumunda ilk sözü A. N. Kuropatkin alır ve "isyana katılan Kırgızların topraklarının tamamını almak ve o toprakları Ruslara vermek gerekir" diye teklifte bulunur. A. N. Kuropatkin bu teklifle beraber Isık - Göl'de Çüy, Kemin bölgesinde yaşayan ve isyana katılan Kırgızları yeni belirlenmiş sınırın dışına sürmek gerekir, der (Moldokasımov, 2012: 66). Baktığımızda adı geçen bölgelerde asırlar boyunca yaşayan 37.330 Kırgız evinin 2.510.361 hektar toprağını alıp sürmeye karar vermiştir. Kışı uzun süren, dağlık, meyve - sebze yetişmeyen Narın bölgesinin zor şartları Slav milletinin yaşaması için uygun değildir, demişlerdir. O dönemler Iısk - Göl bölgesinden 9.325 ev, Çüy bölgesinden 3.846 ev ölümden kaçıp kendiliklerinden Narın'a göç etmişlerdi. Buna ek olarak Çarlık Rusya'sı tarafından 50.525 ev Narın'a göç edilmişti (Moldokasımov, 2012: 67).

Karara bakacak olursak Rus Çarlığının Kırgız halkı için yürüttüğü otoriter politikanın en son noktasının soykırım olduğunu söyleyebiliriz. Karar şu şekildedir:

- Ayaklanan Kırgızları Isık Göl, Kemin, Çüy ve Pişpek bölgelerinden göç ettirmek (temizlemek).

- Ayaklananları Narın eyaletine göç ettirmekle beraber, Narın bölgesini kontrol altına almak.

- Ayaklanan Kırgızları göç ettirdikten sonra boşalan yerlere Rusları yerleştirmek ve Rus halkından oluşan Prejevalsk bölgesini oluşturmak (Kazıbayev, 1996: 100). 


\section{Sonuç}

Sonuç olarak baktığımızda, asırlar boyunca özgür yaşamaya alışan Kırgızları ele geçirmenin bir tek yolu olduğunu Çarlık Rusya'sı çok iyi biliyordu. Bu yol, Kırgızların millî duygularını tamamen yok etmek; özünden vazgeçirip dilini, dinini unutturmak; tarihlerini gizlemek; tarihini kötüleyerek kimseye gereği olmayan eski hayatın kalıntısı diye inandırıp ulu yazar Cengiz Aytmatov'un deyimiyle bir mankurta dönüştürmek ve böylece sadece boğazını düşünen bir köle yaratmaktı.

Birinci Dünya Savaşı'nda Çarlık Rusya'sı, Kırgızları askere almaya başlayınca Kırgızlar isyan etmiş, çoğu Rus askerleri tarafından öldürülmüştür. Tarihçilerin verdiği bilgilere göre bu ayaklanmada 200 bin civarında insan ölmüştür. Bu duruma dayanamayan halk, Çin'e kaçmış ve bu kaçış tarihe "Ürkün” adıyla yazılmıştır.

Geçmişte okutulduğu ve öğretildiği gibi Türkistan'ın, onun içinden Kırgızistan'ın kuzey bölgelerinin Rusya'ya dâhil edilişine "kendi istekleriyle" (dobrovolno), hatta "barış yoluyla" (mirnoe prisoedinenie) demenin tarihî mantığa hiç uymadığı anlaşılmaktadır (Kenensariev, 1997: 308).

1991 y1lında Bişkek’te “Ürkün’ün 75. yıldönümü için bilimsel konferans gerçekleşmiştir. Bu konferansa Özbekistan, Tacikistan gibi komşu ülkelerden 120 bilim adamı katılmış. 1916 yılındaki isyanın amacı ve tarihî önemi ile ilgili konuşmalar yapılmış. Sonuç olarak "Millî mücadele - Rus'a karşı savaş”, “Kırgızistan'daki millî - mücadele devrimci savaş" demişlerdir (Cakıpbekov, 2012: 48).

Genel olarak baktığımızda Kırgızistan'ın Rusya'ya dâhil edilme süreci aşağı yukarı 80 y1lı içine alan uzun bir süreç, aynı zamanda önemli bir tarihi olay olmuştur. Tarihe baktığımızda Çarlık Rusya'sına karşı isyan kadar başka bir isyan Orta Asya'nın XIX. yüzyıl tarihinde hiç olmamıştır. Bundan dolayı bu olayın, XXI. yüzyılda yaşamakta olan Kırgız milletinin hayatında da önemli bir tarihî yeri vardır.

2008 yılında Kırgızistan Büyük Millet Meclisi'nde, Ağustos ayının ilk haftası, Ürkün'de ölenleri anma haftası olarak resmî bir şekilde kabul edilmiştir. "Ar Namıs" (Ar Namus) grubunun milletvekili Kanıbek İmanaliyev ise en önemli meseleyi gündeme getirmiştir. Çin'e kaçarken geçitten geçemeyip ölen çok sayıda insanımızın olduğunu, onların arasında gömülmeden kalan cesetlerin de bulunduğunu belirtmiş ve onları tespit ederek İslami adetlere göre gömmenin bütün Kırgız gençlerinin boyun borcu olduğunu hatırlatmıştır. 2016 yılı “Ürkün” olaylarının 100. yıldönümü olacaktır. Kırgızistan'da "Ulut ordo" hareketinin üyeleri, devlet yöneticilerine ve topluma 1916 yllındaki olaylara tarihî, siyasi değer vermek ve 
"Ürkün'ün 100. Yıldönümünü Anma” töreni yapılmas1 gerektiğini belirtmişlerdir. Çünkü "Ürkün” XX. yüzyılda Kırgız halkının millî trajedisi olmuştur. Belki de Ürkün olmasaydı, Kırgızlar bu kadar kayıp vermeseydi, halkımızın nüfusu şimdikinden çok olurdu. Kim bilir, belki de millî ekonomimiz de güçlü olurdu.

Günümüzde Kırgızistan bağımsız bir cumhuriyettir. Doğrusunu söyleyecek olursak Sovyetler Birliğinin dağılmasıyla diğer Türk cumhuriyetlerinde olduğu gibi Kırgızistan'a da bağımsızlık "altın tepsiyle" sunulmuştur. Ata babalarımızın asırlar boyunca dilediği dileğine, arzusuna kan dökmeden, kayıp vermeden ulaşan Kırgız halkı; geçmiş tarihini, bunun içinden 1916 yllında toprak için verilmiş millî mücadeleyi hiçbir zaman unutmamalı. Bir devletin kökünü toprak oluşturur.

\section{Kaynaklar}

ABRAMZON, S. M. (1971). Kirgizı $i$ ih Etnogenetiçeskie i Istoriko - Kulturnıe Svyazi. Leningrad: Nauka Yayınları.

ARTIKBAYEV, A. (2004). XX Kılımdagı Kırgız Adabiyatının Tarıhı. Bişkek: TAC Yayıncılık. ATTOKUROV, S. (1998). Kırgız Etnografiyası. Bişkek: Uçkun Yayınları.

ARSTANBEK, B. (1990). Tar Zaman. Muras, 36-40.

BAYALINOV, K. (1983). Kurman Cilga. Frunze: Mektep Yayınc1lık.

CAKIPBEKOV, C. (2012). 1916 - C11kı Kötörülüştün Azırkı Kırgız Tarıhnaamesinde İzildenişi. 1916 -Cll: Azattık Kötörülüşü. Bişkek: Biyiktik Yayınları.

CEENBEKOV, C. (1996). Kırgız Ruhundaki Sosyaldık - Filosofiyalık İdeyalar cana Köz Karaştar. Oş: Uçkun Yayınları.

CUSUPOV, K. (1991). Kırgızdar (Sancıra, Tarıh, Muras, Sal). Bişkek: Kırgızistan Yayınevi.

CUSUPOV, K. (1993). Ürkün. Bişkek: Ala - Too Dergisi Yayınları.

KAFESOĞLU, İ. (1992). Türk Adı, Soyu, Türklerin Anayurdu ve Yayılmaları. Türk Dünyası El Kitabl, 1.c.coğrafya - tarih. Ankara: Türk Kültür Araştırma Enstitüsü Yayınları.

KASIMBEKOV, K. (1990). Singan Kılıç. Bişkek: Kırgızistan Yayınevi.

KAZIBAYEV, P. Ş. (1996). 1916-Cılkı Kırgızstandagı Kötörülüş. Bişkek: Kırgızstan Yayınları.

KENENSARIEV, T. (1997). Kırgızstandın Orusiyaga Karatılışı. Bişkek: Kırızzstan Yayınları.

KURMANAALIOĞLU, K. (1990). Muras. (Kalıgul, Arstanbek, Moldo Kllıç, Aldaş Moldo, CENICOK, Toktogul vb). Frunze: Kirgızistan Yayınevi.

MAHMÛD EL - KÂŞGARÎ (2007). Divanü Lugatit Türk. İstanbul: Kabalc1, Yayınları.

MOLDOKASIMOV, K. S. (2012). 1916-C11. Erkindik Üçün Küröştün Baraktarı cana Sabakatarı.1916 -Cıl. Azattık Kötörü̈lüşü. Bişkek: Biyiktik Yayınları.

MOLDO KILIÇ, Ş. (1990). Zar Zaman. Muras. Bişkek: Kırgızstan Yayınları.

SOLTONOYEV, B. (1993). Kızıl Kırgız Tarıhı. Bişkek: Uçkun Yayınevi.

TOKOMBAYEV, A. (1999). Kanduu Cıldar. Bişkek: Erkin Yayınevi. 